\title{
A Study on Impact of Ageing on Self Esteem
}

\author{
Reena Rawal ${ }^{1}$ and Anshu ${ }^{2 *}$ \\ Department of Extension Education and Communication Management, CCS Haryana \\ Agricultural University, Hisar-125004 (Haryana), India \\ *Corresponding author
}

\section{A B S T R A C T}

\section{Keywords \\ Old age, \\ Psychological \\ Wellbeing and Self- \\ Esteem \\ Article Info \\ Accepted: \\ 15 January 2019 \\ Available Online: \\ 10 February 2019}

Old age involves a number of other changes that might contribute to declines in selfesteem, including spousal loss, decreased social support, declining physical health, cognitive impairments. Main objective of the study is to measure impact of ageing on selfesteem of older people and to find the factors affecting the self-esteem of older people. Self -esteem of the respondents was measured on three different aspects- Performance selfesteem, Social self-esteem and Appearance self-esteem. Result indicated that nearly half of the respondents had medium and high level of Performance self-esteem and medium level of Social self-esteem. Majority of the respondents had medium level of Appearance selfesteem followed by low level of Appearance self-esteem. It was found that the respondents who have higher level of education had high level of performance self -esteem.

\section{Introduction}

Self-esteem is a psychological term that reflects a person's overall evaluation of his or her worth, it encompasses beliefs ("I am competent", I am worthy") and emotions (triumph, despair, pride and shame). It is used to describe a person's overall sense of selfworth or personal value (Cherry, 2010). It is basically one's opinion about one's self. People with a strong sense of self-efficacy can view challenges as tasks to be mastered, while they develop deeper interests in the task or activities that they are currently participating in. They are more resilient and able to try again when they don't succeed in performing those tasks, while people with a weak sense of self-efficacy tend to avoid challenging tasks. It is the subjective measure of a person's value, the worth that one believes one has as an individual, while self-efficacy is a person's belief about their capabilities to produce designated levels of performance that exercise influence over events affecting their lives (Onyishi and Ogbodo, 2012).

Old age involves a number of other changes that might contribute to declines in selfesteem, including spousal loss, decreased social support, declining physical health, cognitive impairments, and a downward shift in SES (Baltes and Mayer, 1999). Education, income, health and employment status all had some effect on the self esteem trajectories, 
especially as people aged. "Specifically, people who have higher incomes and better health in later life tend to maintain their selfesteem as they age (Orth et al., 2010).

Keeping the context the study will be conducted with the following objectives:-

1. To measure impact of ageing on self esteem of older people

2. To find the factors affecting the self esteem of older people

\section{Materials and Methods}

The study was conducted in randomly selected state Haryana. - Randomly selection of 20 respondents from rural and 20 from urban area of Hisar, thus a total no. of 40 respondents were selected for the study. Keeping in view the objectives of investigation well structured interview schedule was constructed in accordance of independent variable and for dependent variable (Current Thoughts Scale (Heatherton and Polivy, 1991 was used). The collected data was coded, tabulated and interpreted by using percentages, frequency and correlation. Correlation coefficient was employed to find out the relationship of independent variables with dependent variables.

\section{Results and Discussion}

\section{Socio-personal profile of the respondents}

The socio- personal profile of the respondents indicated that most of the respondents $(60.00 \%)$ were in the age group of $60-67$ years followed by 40.00 percent who were in the age of 68-75 years. The gender wise distributions revealed that most of the respondents $(65.00 \%)$ were male followed by female $(35.00 \%)$. Majority of the respondent (60.00) were from urban area. The caste wise distributions of the respondents reveal that most of the respondents $(55.00 \%)$ belonged to upper caste followed by $25.00 \%$ and $20.00 \%$ who belong to backward Caste and SC/ST caste respectively.

More than one fourth of the respondents (35.00\%) were illiterate. Only 20.00 per cent of respondents had obtained formal schooling up to metric and graduates level followed by high school (15.00\%) and primary school s $(10.00 \%)$. Majority of the respondents $(95.00 \%)$ were married followed by 5 per cent respondents who were widow.

Nearly fifty per cent $(40.00 \%)$ of the respondents had medium and high level of Performance self-esteem followed by low $(20.00 \%)$. Nearly half of the respondents $(45.00 \%)$ had medium level of Social selfesteem followed by high $(40.00 \%)$ and low $(15.00 \%)$ level of Social self-esteem and majority of the respondents $(60.00 \%)$ had medium level of Appearance self-esteem followed by low (45.00\%) and high $(5.00 \%)$ level of Appearance self-esteem. The result presented in the table 1 indicated that more than one third of the respondents $(40.00 \%)$ had medium and high level of self - esteem followed by low (20.00\%).

\section{Factors affecting the self - esteem of the respondents}

In order to find out the relationship between independent variables with the self esteem of the respondents Pearson product correlation coefficient was applied. The data pertains to these aspect have been presented in the following table 2 .

\section{Correlation between respondent's independent variables and their performance self-esteem}

The data reported in the Table 3 revealed that education found to be positively correlated 
with the performance self -esteem of the respondents. Respondents who have high level of education had high level of performance self -esteem and caste was found to be significant but negatively correlated at 5\%level of significance. Respondents who belong to lower caste had more performance self-esteem.

\section{Correlation between respondent's} independent variables and their Social selfesteem

Table 4 indicated that locality and caste found to be significantly but negatively correlated with Social self esteem. Respondents who were form rural area and who belong to lower caste had high level of self -esteem. The data further reveal that one other variable viz., education was found positively significant at $5 \%$ level of significance. Respondents who had high level of education were having high level of social self-esteem.

\section{Correlation between respondent's independent variables and their appearance self-esteem}

Result indicated that marital status was found to be significantly but negatively correlated with appearance self- esteem of the respondents (Table 5).

Table.1 Socio-personal profile of the respondents

\begin{tabular}{|c|c|c|c|c|}
\hline & & & & $N=4$ \\
\hline Sr.no & Variables & Categories & Frequency & Percentage \\
\hline 1 & Age & Older (60-67 years) & 24 & 60.00 \\
\hline & & Older (68-75years) & 16 & 40.00 \\
\hline 2 & Gender & Male & 26 & 65.00 \\
\hline & & Female & 14 & 35.00 \\
\hline 3 & Locality & Rural & 16 & 40.00 \\
\hline & & Urban & 24 & 60.00 \\
\hline 4 & Caste & $\mathrm{SC} / \mathrm{ST}$ & 8 & 20.00 \\
\hline & & Backward & 10 & 25.00 \\
\hline & & Upper cast & 22 & 55.00 \\
\hline 5 & Family type & Nuclear & 6 & 15.00 \\
\hline & & Joint & 34 & 85.00 \\
\hline 6 & Family size & Up to 4 members & 6 & 15.00 \\
\hline & & 4-6 members & 20 & 50.00 \\
\hline & & Above 6 members & 14 & 35.00 \\
\hline 7 & Marital status & Married & 38 & 95.00 \\
\hline & & Widow & 2 & 5.00 \\
\hline & & Divorce & - & - \\
\hline 8 & Respondent education & Illiterate & 14 & 35.00 \\
\hline & & Primary school & 4 & 10.00 \\
\hline & & Middle school & - & - \\
\hline & & Metric school & 8 & 20.00 \\
\hline & & High school & 6 & 15.00 \\
\hline & & Graduate and above & 8 & 20.00 \\
\hline
\end{tabular}


Table.2 Self-esteem of the respondents

\begin{tabular}{|c|c|c|c|c|}
\hline & & & & \\
\hline Sr.no & Self- esteem & Categories & Frequency & Percentage \\
\hline \multirow[t]{3}{*}{1} & \multirow[t]{3}{*}{ Performance self-esteem } & Low (18-22) & 8 & 20.00 \\
\hline & & Medium (23-27) & 16 & 40.00 \\
\hline & & High $(28-32)$ & 16 & 40.00 \\
\hline \multirow[t]{3}{*}{2} & \multirow[t]{3}{*}{ Social self-esteem } & Low $(28-32)$ & 6 & 15.00 \\
\hline & & Medium (33-37) & 18 & 45.00 \\
\hline & & High $(38-42)$ & 16 & 40.00 \\
\hline \multirow[t]{3}{*}{3} & \multirow[t]{3}{*}{ Appearance self-esteem } & Low (20-23) & 14 & 35.00 \\
\hline & & Medium(24-27) & 24 & 60.00 \\
\hline & & $\operatorname{High}(28-31)$ & 2 & 5.00 \\
\hline \multirow[t]{3}{*}{4} & \multirow[t]{3}{*}{ Over all } & Low (73-81) & 8 & 20.00 \\
\hline & & Medium(82-90) & 16 & 40.00 \\
\hline & & High (91-99) & 16 & 40.00 \\
\hline
\end{tabular}

Table.3 Correlation between independent variables and Performance self-esteem

\begin{tabular}{|l|l|l|}
\hline Sr.no & Variables & r value \\
\hline $\mathbf{1}$ & Age & 0.051 \\
\hline $\mathbf{2}$ & Locality & -0.350 \\
\hline $\mathbf{3}$ & Caste & $-0.556^{*}$ \\
\hline $\mathbf{4}$ & Family type & -0.232 \\
\hline $\mathbf{5}$ & Family size & 0.040 \\
\hline $\mathbf{6}$ & Marital status & -0.435 \\
\hline $\mathbf{7}$ & Education & $0.692^{*}$ \\
\hline
\end{tabular}

*Significance at $5 \%$ level

Table.4 Correlation between independent variables and Social self-esteem

\begin{tabular}{|l|l|l|}
\hline Sr.no & Variables & r value \\
\hline $\mathbf{1}$ & Age & 0.098 \\
\hline $\mathbf{2}$ & Locality & $-0.540^{*}$ \\
\hline $\mathbf{3}$ & Caste & $-0.612^{*}$ \\
\hline $\mathbf{4}$ & Family type & 0.030 \\
\hline $\mathbf{5}$ & Family size & -0.210 \\
\hline $\mathbf{6}$ & Marital status & -0.089 \\
\hline $\mathbf{7}$ & Education & $0.554^{*}$ \\
\hline
\end{tabular}

*Significance at $5 \%$ level 
Table.5 Correlation between independent variables and appearance self-esteem

\begin{tabular}{|l|l|l|}
\hline Sr.no & Variables & r value \\
\hline $\mathbf{1}$ & Age & 0.047 \\
\hline $\mathbf{2}$ & Locality & -0.136 \\
\hline $\mathbf{3}$ & Caste & -0.249 \\
\hline $\mathbf{4}$ & Family type & -0.190 \\
\hline $\mathbf{5}$ & Family size & -0.330 \\
\hline $\mathbf{6}$ & Marital status & $-0.446^{*}$ \\
\hline $\mathbf{7}$ & Education & 0.318 \\
\hline
\end{tabular}

*Significance at 5\% level

In conclusions, self-esteem of the respondents was measured on three different aspects and the study concluded that education have a positive impact on self esteem, it was found that the respondents who have high level of education had high level of performance self -esteem. Similar finding were reported by Orth et al., (2010) that Education, income, health and employment status all had positive effect on the self-esteem trajectories, especially as people aged. The data further indicated that the locality and caste found to be significantly but negatively correlated with Social self esteem. Respondents who were form rural area and who belong to lower caste had high level of self-esteem.

\section{References}

Baltes, P. B., and Mayer, K. U. (Eds.). (1999). The Berlin Aging Study: Aging from 70 to 100. Cambridge, England: Cambridge University Press.

Goswami, P. (2013). Ageing and Its Effect on Body-Self Image, Mood and Self
Esteem of Middle Age Women and Older Women. IOSR Journal of Humanities and Social Science).Vol. 18(5): 63-73.

Potter, J., Robins, R.W., Trzesniewski, K.H., Tracy, J.L and Gosling, S.D. (2002). Global Self-Esteem Across the Life Span. Psychology and Aging. Vol. 17(3): 423-434.

Orth, U., Robins, R.W. and Trzesniewski, K.H. (2010). Self-Esteem Development from Young Adulthood to Old Age: A Cohort-Sequential Longitudinal Study. Journal of Personality and Social Psychology. Vol. 98(4): 645-658.

Tiggemann, M., and Lynch, J. E. (2001). Body image across the life span in adult women: The role of self-objectification. Developmental Psychology. Vol. 37: 243-253.

Orth et. al. (2012) Life-Span Development of Self-Esteem and Its Effects on Important Life Outcomes. Journal of Personality and Social Psychology. Vol. 102(6): 1271-1288.

\section{How to cite this article:}

Reena Rawal and Anshu. 2019. A Study on Impact of Ageing on Self Esteem. Int.J.Curr.Microbiol.App.Sci. 8(02): 1747-1751. doi: https://doi.org/10.20546/ijcmas.2019.802.206 